\title{
Mathematical communication skills based on cognitive styles and gender
}

\author{
Kamid ${ }^{1}$, M. Rusdi ${ }^{2}$, Olva Fitaloka ${ }^{3}$, Fibrika Rahmat Basuki ${ }^{4}$, Khairul Anwar ${ }^{5}$ \\ 1,3,5 Department of Mathematics Education, Universitas Jambi, Indonesia \\ ${ }^{2}$ Department of Chemistry Education, Universitas Jambi, Indonesia \\ ${ }^{4}$ Department of Physics Education, Universitas Jambi, Indonesia
}

\begin{tabular}{l} 
Article Info \\
\hline Article history: \\
Received Jan 25, 2020 \\
Revised Sep 14, 2020 \\
Accepted Oct 24, 2020 \\
\hline
\end{tabular}

\section{Keywords:}

Cognitive style

Gender

Mathematical communication

\begin{abstract}
This research aimed to determine the differences of mathematical communication skills based on cognitive styles and gender. This research was a mixed-method with sequential explanatory design. The population was grade XI students at Senior High School in Jambi City consisting of 53 male and 72 female students. The study used a total sampling. The key informant consisted of four field independent and four field dependent. The instruments were used cognitive style test, mathematical communication test, and interviews. The differences of mathematical communication skills were analyzed using Mann-Whitney U-Test. Qualitative data were analyze descriptively using Miles and Huberman model. The results of this study showed that there was a significant difference of Field Independent (FI) and Field Dependent (FD) students in mathematical communication skills. FI can explain the information on the question well, using the mathematical model appropriately, explaining the problem-solving strategy very clear and structured, and being able to evaluate clearly and accurately. FD able to describing the information on the matter, but less complete, using the mathematical model appropriately, explaining the problem-solving strategy, but less complete, and being able to evaluate it quite clearly. The mathematical communication skills of male and female students were not significant differences. Male students are able to explain the strategy and the steps of solving the problem quite clearly, but less structured. Female students are able to explain the strategy and steps to resolve the problem clearly and structured.
\end{abstract}

This is an open access article under the CC BY-SA license.

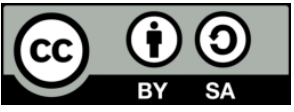

\section{Corresponding Author:}

Olva Fitaloka,

Mathematics Education Department,

Universitas Jambi,

36361 Jl. Jambi-Ma. Bulian KM 15 Mendalo Indah, Jambi, Indonesia.

Email: olvafitaloka@gmail.com

\section{INTRODUCTION}

Mathematical communication skill is an ability to express mathematical ideas, understand, interpret, assess or respond mathematical ideas and use terms, notations, and symbols to present mathematical ideas [1]. Mathematical communication is standards that must be developed in mathematics education. This standard emphasizes that students are able to "use mathematical language to express mathematical ideas, organize and consolidate their thoughts communication." They are also able to "analyze and evaluate the mathematical thinking and the strategies of others and communicate their mathematical thoughts coherently and clearly to peers, teachers, and others" [2]. When students communicate their thoughts to others in verbal 
or writing will help to improve understanding, make connections and develop languages to express mathematical ideas. It has contribute to promoted students' conceptual understanding, problem-solving, and correct misconceptions about mathematical concepts [3,4]. The mathematical communication skills is influenced by cognitive style [5,6]. The finding of Junita's study [7] showed that there was a difference in the mathematical representation and communication skills of field independent and field dependent students.

Cognitive styles are characteristic of each individual in the use of a cognitive function that is displayed through perceptual and intellectual activity consistently [8]. It can be defined as how one thinks and processes information, both globally and analytically in certain situations [9]. Cognitive style refers to the characteristics of a person in responding to, processing, storing, thinking, and using the information to respond to a task or various environmental situations [10]. From some of the above opinions can be concluded that cognitive style is an individual characteristic in thinking, responding to, processing, storing consistent information. Each student has a different cognitive development and level of thinking, so it will show a difference in responding and processing the information encountered. Analytic-based global continuous cognitive styles are differentiated into field-independent (FI) and field-dependent (FD) [11]. The cognitive style by dimension, namely: (a) the psychological aspect difference, consisting of the field independence (FI) and field dependence (FD); (b) the time of concept comprehension, consisting of impulsive style and reflective [12].

Cognitive style is distinguished into a reflective-impulsive cognitive style that demonstrates the speed of thinking [13]. Field dependent is a person who thinks globally, receives existing structures or information, has a social orientation, chooses a profession that is social skills, tends to follow the purpose and information is already there and tends to prioritize external motivation [11]. They are receive something globally and have difficulty separating themselves from surrounding circumstances or more influenced by the environment, tend to know himself as part of the group [14]. Field independent are individuals with characteristics capable of analyzing objects separated from their environment, able to organize objects, have impersonal orientation, choose a profession that is Self-motivation [11]. FI are not affected by the environment [15]. They are view analytical issues, able to analyze and isolate relevant details, detect patterns, and critically evaluate an issue [16]. From some of the above opinion can be concluded that the fieldindependent is a characteristic of individuals who tend to look at objects consist of discrete parts and separate from their environment and able to analyze in separating elements of the context more analytic. The fielddependent is an individual characteristic that tends to organize and process information globally so that the perception is easily affected by environmental change. How to process and respond to information will affect the ability to communicate in mathematics orally and in writing.

The gender difference also determines the communication patterns of both oral and written. The man dominant use spatial abilities while the female uses logical reasoning. The results of the study [17] showed that the oral mathematical communication of male students who had high mathematical abilities was more accurate than female students who had high mathematical abilities. The characteristics of male are aggressive, competitive, confident, want to appear and higher self-esteem than female. The characteristics of girls are more proficient in the language, having sensory awareness, memory, social awareness and relationships with other parties. Gender difference is also possible as an influential factor in student writing and oral communication in solving mathematical problems. According to Nafi' an [18] the difference between men and women in mathematics learning is that men are superior in reasoning, mathematical and mechanical skills while women are superior to precision, thoroughness, accuracy, and equality of thinking. The difference is not real at the elementary school level but it becomes clearer looking at a higher level. The opinion demonstrates a high ability for boys in terms of mathematics, but women are superior in their effective aspects (diligent, thorough, meticulous).

Men and women have different abilities such as the women have higher verbal abilities than men, men are superior to the ability visual-spatial than women, and the men are superior to mathematical abilities [19]. The differentiator factor between men and women is in language and skill [20]. Parents prefer to communicate with girls than boys so that the vocabulary of girls is estimated to be more than boys. The comparison of these two genders makes women appear to be more active in speaking compared to the male gender. According to Yuliani [21], women use their left side brains to listen and talk where communication activities occur more using the left brain. Thus, the left brain plays a leading role in language mastery by women. The characteristics of boys are aggressive, competitive, confident, want to appear and higher selfesteem than girls. The characteristics of girls are more proficient in the language, having sensory awareness, memory, social awareness and relationships with other parties.

The purpose of the research was determining the students' differences of mathematical communication skills base on cognitive styles and gender at state senior high school in Jambi, Indonesia. The mathematical communication skills have important role in mathematical problem solving and learning 
achievements. Students who have mathematical communication skills will be able to use the language of mathematics to reveal ideas, organize and consolidate the mathematical thinking.

\section{RESEARCH METHOD}

This research was a mixed method using a sequential explanatory design [22]. Data collection consisted of the quantitative data and qualitative data collection. The sequential explanatory design is shown in Figure 1. The primary method used the ex-post facto design shown in Table 1. The ex-post-facto study outlines the influence between a variable and the other variables in which the free variables have occurred and not performed controls or manipulation. The free variables in the study are cognitive style and gender, while bonded variables are the ability of mathematical communication. The secondary method used qualitative descriptive. The qualitative data collection was interview to the key informant. Furthermore, data were analyzed to describe the mathematical communication skills based on cognitive style and gender.

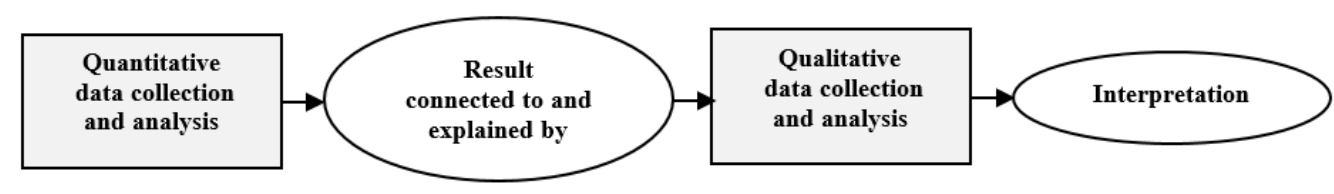

Figure 1. Sequential explanatory design

Table 1. The ex-post-facto design

\begin{tabular}{ccc}
\hline \multicolumn{3}{c}{ Cognitive Style (X) } \\
\multirow{2}{*}{ Gender $(\mathrm{C})$} & FI (X1) & FD (X2) \\
\hline Male $(\mathrm{C} 1)$ & Y (X1C1) & Y (X2C1) \\
Female $(\mathrm{C} 2)$ & Y (X1C2) & Y (X2C2) \\
\hline Y (X1C1) = mathematical communication of FI male students \\
Y (X2C1) = mathematical communication of FD male students \\
Y (X1C2) = mathematical communication of FI female students \\
Y (X2C2) = mathematical communication of FD female students
\end{tabular}

\subsection{Population and samples}

The population in this study is grade XI MIA student at Senior High School in Jambi City, Indonesia consisting of 53 male students and 72 female students. The study employed total sampling technique. The problems that occur in these schools are relevant to the research topic of mathematics communication skills and problem solving.

\subsection{Key informant}

Key informants were selected based on the research variables regarding cognitive style and gender. The key informant consists of four students of field independent and four students of field dependent. Key informants were further grouped based on gender (male and female) as shown in Table 2. Key informants were chosen because they could provide information about students' mathematical communication skills based on cognitive style groups field independent and field dependent and gender groups (male and female).

Table 2. The key informant

\begin{tabular}{ccc}
\hline \multirow{2}{*}{ Cognitif style } & Male & Female \\
\hline Field Independent & 2 students & 2 students \\
Field Dependent & 2 students & 2 students \\
Total & 4 students & 4 students \\
\hline
\end{tabular}

\subsection{The instruments}

\section{a. Cognitive style test (GEFT)}

Group Embedded Figure Test (GEFT) adapted from [7]. The GEFT has been validated by experts. This instrument consists of three groups of questions. The first group consists of 7 items, the second and third group consists of 9 items. The questions at first group were not scored because the group was intended as an 
exercise for the students. The second and third questions were scored 1 if answered correctly and 0 if answered incorrectly. The highest score that can be obtained by respondents was 18 . The time allocated for the first group was two minutes and for the second and third groups respectively five minutes.

\section{b. Mathematics communication test}

The mathematical communication test used essay test consisting of six items on the topic of the twovariable linear equation system. Mathematical communication tests have been validated by experts. Test items are conducted on material aspects, construction aspects, and language aspects [23].

\section{c. Interview guidelines}

Interview guidelines are used to collect data on oral mathematical communication skills. The interview guidelines contain a list of questions consisting of eight questions. Interviews are conducted to confirm the answer orally.

\subsection{Data analysis}

Descriptive analysis was begun with the scoring of GEFT results. The GEFT scores are categorized to determine student's cognitive style criteria according to Table 3 [9]. The mathematical communication score test was conducted by five scales $(4,3,2,1,0)$. The maximum score can be gained is 24 and the minimum score is 0 . Scores are converted to determine the level of mathematical communication skills [24]. The criterion was determined by the modification sections Maine Holistic Rubric for Mathematics, Maryland Math Communication and QUASAR General Rubric [25].

Table 3. Cognitive style criterion

\begin{tabular}{cc}
\hline Cognitive style & Score \\
\hline Field Dependent & $0 \leq$ GEFT $<7$ \\
Intermediate & $7 \leq$ GEFT $<13$ \\
Field Independent & $13 \leq$ GEFT $\leq 18$ \\
\hline
\end{tabular}

The hypothesis test was conducted to test the average difference in mathematical communication skills based on cognitive styles and gender. The hypothesis test was conducted with Mann-Whitney U-test (non-parametric). The Mann-Whitney U-Test is an equivalent statistical test with T-Test for independent samples. There are several criteria in the Mann-Whitney U-Test (non-parametric) elections including data in the form of ordinal or nominal data, small sample size, non-distribution of normal data and having a variance that is not equal/not homogeneous [26]. The Mann-Whitney test was conducted with the help of the SPSS 22.0 program with an equivalent of $5 \%$ significance. The criteria of the decision to be used are rejected $\mathrm{H}_{0}$ if the value significance $\leq 0.05$. Qualitative data were analysis descriptively that consist data collection, data reduction, data presentation, data analysis, and conclusions. The analysis was conducted to describe the mathematical communication skills based on cognitive style and gender.

\section{RESULTS AND DISCUSSION}

The data collection of cognitive-style was conducted through the Group Embedded Figure Test (GEFT) modified from [7]. Distribution of students' cognitive-style test results shown in Table 4. From Table 4, it is seen that the respondents were grouped into three categories namely the field-dependent, intermediate, and filed independent cognitive styles. But the subject of this research is only students with the cognitive style of field-independent and field-dependent. It is because the field-independent and the dependent field have very different characteristics in processing information. The field independent (FI) is a characteristic of individuals who tend to look at objects consisting of discrete parts and separate from their environment and are able to analyze in separating elements from the context more analytic. The fielddependent (FD) is a characteristic of individuals who tend to organize and process information globally so that the perception is easily affected by environmental change. From the GEFT results, the number of research subjects taken is 55 students that consists 26 males and 29 females. 
Table 4. Frequency distribution of students' cognitive style

\begin{tabular}{ccc}
\hline Range & Cognitive style & Frequency \\
\hline $0 \leq$ GEFT $<7$ & Field Dependent & 20 \\
$7 \leq$ GEFT $<13$ & Intermediate & 70 \\
$13 \leq$ GEFT $\leq 18$ & Field Independent & 35 \\
& Total & 125 \\
\hline
\end{tabular}

\subsection{Mathematical communication test results based on cognitive style}

The mathematical communication test results are grouped by field-independent and field-dependent. The result of the mathematical communication test is categorized into 5 levels based on the modifications of the Maine Holistic Rubric for Mathematics, Maryland Math Communication, and QUASAR General Rubric [25]. The average mathematical communication skills of the students' group's field-independent and the field-dependent cognitive-style are shown in Table 5. The average of the mathematical communication skills of FI students is 11.69 which is at level 2 with a medium category. The average mathematical communication skill of FD students is 7.90 which is at level 1 with a low category.

Table 5. The average of mathematical communication of FI and FD students

\begin{tabular}{ccc}
\hline Statistic & \multicolumn{2}{c}{ Cognitive style } \\
description & Field Independent & Field Dependent \\
\hline Mean & 11.69 & 7.90 \\
Std. Deviation & 4.963 & 3.892 \\
Varian & 24.634 & 15.147 \\
Minimum & 3 & 1 \\
Maximum & 21 & 17 \\
\hline
\end{tabular}

\subsection{Differences in mathematical communication skills based on cognitive style}

The hypothesis test to determine the average rate of mathematical communication based on the cognitive style is conducted using the Mann-Whitney U-Test test. Mann-Whitney U-Test results can be seen in Table 6. Based on the results of Mann-Whitney U-Test, acquired the significance value of mathematical communication $0.005<0.05$, so $\mathrm{H}_{\mathrm{o}}$ is rejected. It shows that there is a significant difference in the average mathematical communication skills of the field-dependent and field-independent students. The average mathematical communication capability of field-independent students is higher than that of field-dependent cognitive-style students.

Table 6. Mann-Whitney U-test of mathematical communication based on cognitive style

\begin{tabular}{cc}
\hline & Mathematical Communication \\
\hline Mann-Whitney U & 190.500 \\
Wilcoxon W & 400.500 \\
Z & -2.803 \\
Asymp. Sig. (2-tailed) & 0.005 \\
\hline a. Grouping Variable: Cognitive style
\end{tabular}

The results of this study are in line with [7] that there is a difference in the mathematical communication skills of the students who are field-dependent and field-independent students. Fieldindependent students have better skills in mathematical communication. The results of the study [27] demonstrated the ability of mathematical communication of students with the cognitive style of FD different from those of FI students. FD students can communicate ideas in writing well but they struggle to communicate ideas orally and inclination to receive information without reorganizing in such a way that problem-solving ideas. They can't disclose the solution to the actual problem. Meanwhile, FI students can communicate ideas orally and write well and reorganize information in such a way that the presented problem-solving ideas can reveal a solution to the real problem.

The different ways of thinking between FI and FD students in processing information allow the difference between write and verbal communication in solving mathematical problems. FI students have an analytical characteristic of thinking, can separate objects from the surrounding environment so that the perception is not affected in case of changes in context and shows separate parts of the overall pattern and is able to analyze Patterns into its components. FD students have characterized difficulties in processing information, tend to only receive information provided and are unable to reorganize, analyze patterns into different sections, and view objects and converge with the environment [11]. FI students' demonstrated better 
performance than the FD student group because of their ability to distinguish important and relevant information from irrelevant ones [28]. FD students do not have this ability, so the unimportant and irrelevant things occupy their working memory space. Based on the results of the study, it was seen that the average mathematical communication skills of FI students were at level 2 with a medium category. The average mathematical communication skills of FD students were at level 1 with a low category. It indicates that the mathematical communication skills of FI and FD students are still relatively low, so they need to be improved again. Math learning activities must be developed to improve mathematical communication by applying the right model and approach. Problem-solving and mathematical communication skills by using realistic mathematical approaches are higher than those with converged learning [29]. Mathematical communication skills can be improved by developing a basic understanding of student mathematics including mathematical definition rules, making the model of a situation through writing, concrete objects, images, graphs, and methods of algebra, drafting reflections and clarifying mathematical ideas, using the ability to polish, listen to, and observe to interpret and evaluate a mathematical idea, discuss ideas, make conjectures, drafting arguments, defining definitions, and generalizations [4].

\subsection{Mathematical communication test results based on gender}

The data of mathematical communication is grouped by male and female gender. The result of the mathematical communication test is categorized into 5 levels based on the modifications of the Maine Holistic Rubric for Mathematics, Maryland Math Communication and QUASAR General Rubric [25]. The average mathematical communication skills of students in male and female groups are shown in Table 7 . The average of the mathematical communication skills of male students is 9.23 which is at level 1 with a low category. The average mathematical communication capability of female students is 11.28 which is at level 2 with a medium category.

Table 7. The average of mathematical communication of male and female students

\begin{tabular}{ccc}
\hline \multirow{2}{*}{ Statistic description } & \multicolumn{2}{c}{ Gender } \\
& Male & Female \\
\hline Mean & 9.23 & 11.28 \\
Std. Deviation & 4.043 & 5.483 \\
Varian & 16.345 & 30.064 \\
Minimum & 3 & 1 \\
Maximum & 18 & 21 \\
\hline
\end{tabular}

\subsection{The differences in mathematical communication skills based on gender}

The hypothesis test to determine the average rate of mathematical communication skills based on gender is conducted using the Mann-Whitney U-Test test. Mann-Whitney U-Test results can be seen in Table 8. Based on the results Mann-Whitney U-Test acquired the significance value of mathematical communication $0.229>0.05$ so that $\mathrm{H}_{0}$ received. It shows that there is no significant difference in the average mathematical communication capabilities of male students and female students. According to Goos [30] the difference of students' mathematical learning results influenced by gender differences has not been consistent, some studies have shown differences (men are better than women or vice versa) and some do not show differences Both. In general, gender differences in mathematical learning achievement depends on the contents of the task, the nature of the assigned knowledge and skills, and the conditions when working on the task.

Table 8. Mann-Whitney U-Test of mathematical communication based on cognitive style

\begin{tabular}{cc}
\hline & Mathematical Communication \\
\hline Mann-Whitney U & 306.000 \\
Wilcoxon W & 657.000 \\
Z & -1.202 \\
Asymp. Sig. (2-tailed) & 0.229 \\
\hline
\end{tabular}

a. Grouping Variable: Gender

The results of this study differ from the results of the study [31] showed that the mathematical communication skills of female students both in writing and orally in resolving differential equations are better if compared to male students. According to Amir [32], female students are superior in mathematical 
(verbal) communication skills, more motivated, organized in learning. From two opinions above it is seen that the qualitative communication skills of female students are better than male students.

While the research results [17] a mathematical communication of male students who have high mathematical skills is more accurate than in female students who have high mathematical skills. Male students tend to be better at verbal communication in writing, while female students are better at oral mathematical communication [33]. Male students open-minded, able to think the abstract mathematically, and find different patterns of answers. While the subject of women in concrete thinking, difficult to think abstract so it is difficult to find common patterns. But women are more fluent in revealing his written answer [34]. The subject of male writing mathematics communication ability is accurate, complete and smooth. The ability of communication of women subject in writing is accurate except using a condition/formula, complete except creating an image/sketch as well as using the condition/formula can not be determined, smoothly except creating an image/sketch and using the condition/formula can not be determined [35]. Male students are orally able to express mathematical ideas, demonstrate mathematical ideas, convey mathematical ideas, understand mathematical ideas, interpret mathematical ideas, evaluate mathematical ideas, use the term, mathematical notation and the structure, convey mathematical ideas using terms, mathematical notation, and its structure, convey ideas and relationships with the model situation. Female students are able to express mathematical ideas, demonstrate mathematical ideas, convey mathematical ideas, understand mathematical ideas, interpret mathematical ideas, evaluate mathematical ideas, able to use the term, mathematical notation and the structure, convey mathematical ideas using terms, mathematical notation and its structure, convey ideas and relationships with the model situation [36].

\subsection{FI student in mathematical communication}

The mathematical communication of the male student FI shows a different pattern between the highest score (FI1) and the lowest (FI2) students. The FI1 subject can understand the information contained in the question. He can explain what is known and well-asked. He use notation, symbols, and mathematical models to describe the problem/answer appropriately. He is able to explain the strategy and the steps to resolve the problem with a clearly but less structured. He also able to explain how to evaluate/check the settlement clearly and accurately. While the FI 2 subject can understand the information contained in the question. He explan what is known and asked but less precise and uncomplete. He can't describe problems with mathematical models. The explanation of problem solving strategy is unclear. He can't explan how to evaluate/check the problem solving.

The mathematical communication pattern of the female student FI shows a different pattern between the highest score (FI3) and the lowest (FI4) students. The FI3 subject has the correct answer, a complete explanation, a very clear prolem solving strategy, using very effective and accurate mathematical language. She can understand the information on the question well. She is able to redefine what is known and asked precisely and clearly. She use notation, symbols, and mathematical models to describe the problem appropriately. She is able to explain the strategy and the steps to resolve the problem with a very clear and structured. She is able to explain how to evaluate/check the settlement clearly and accurately. While FI4 subject can understand the information contained in the question well, able to explain what is well known but can not explain what is being asked exactly and complete. She describe the problem using the mathematical language/mathematical model but less precise. The explanation of strategy and troubleshooting steps are less obvious and less precise. Explanation of how to evaluate/check the problem solving is less obvious and less accurate.

The FI1 and FI3 subjects are differences in explaining the strategy and problem-solving steps women students more accurately than men. It is in line with the research results [25] that FI female students in describing the problem visually are performed based on appropriate analysis and according to the troubleshooting steps, applying a geometry concept to problem-solving well. While FI male students tend to dable in or include other images to convince answers. FI students are able to explain the situation, present problems, represent mathematics in whole and a part, use concepts and strategies, solve problems, obtain solutions, and interpret the solution [37]. The FI is a characteristic of individuals who tend to look at objects consisting of discrete parts and separate from their environment and are able to analyze in separating elements from the context in more analytic terms. The results of the study [38] that FI students were able to express mathematical ideas, understand, interpret and evaluate mathematical ideas, use the terms, mathematical notation and structures to presenting ideas, describing relationships with model situations. The student with field-independent cognitive style is able to express mathematical ideas, interpret and describe mathematical ideas correctly in the form of solving problems, and write symbols and mathematical notation to present mathematical ideas carefully, correctly and in accordance with the rules [39]. 


\subsection{FD student in mathematical communication}

The mathematical communication pattern of the FD male students shows a different pattern between the highest score (FD1) and lows (FD2) students. The FD1 subject is the correct answer, quite complete explanation, quite obvious the completion strategys, quite effective and accurate in using a mathematical language. He can understand the information contained in the question well, but the explanation of what is known and asked less clearly and less complete. He use notation, symbols, and mathematical models to describe the problem appropriately. He is able to explain the strategy and troubleshooting steps but are less complete. He is able to explain how to evaluate/check the settlement fairly clearly and accurately. While the FD2 subject can understand the information contained in the matter well enough. He can explain what is known but less complete. He can't explain what was asked about the question. He can't describe problems with mathematical models. He can't explain the strategy and the steps to resolve the problem. The evaluate the problem is less clear and less accurate

The mathematical communication pattern of the FD female students shows a different pattern between the students earning the highest score (FD3) and the lowest (FD4). The FD3 subject has the correct answer, a complete explanation, a very clear completion strategy, using a very effective and accurate mathematical language. She can understand the information contained in the question well. She is able to redefine what is known and asked clearly and fully. She describe problems using mathematical language (notation, symbols, and models) appropriately. She is able to explain the strategy and the steps to resolve the problem clearly and structured. She is able to explain how to evaluate/check the settlement precisely and accurately. While the FD4 subject does not answer the question. This shows that the mathematical communication skills in writing are at level 0 very low category. She cannot understand the information contained in the question properly, unable to re-explain what is known and asked clearly and fully. She describe the problem using mathematical language (notation, symbols, and mathematical models) but are precise and incomplete. She explain the strategy and the steps to resolve the problem but are less obvious and less structured. She can't explain how to evaluate/check.

Female students have more accurate communication than male students for all indicators. Male students are less clear and less complete in explaining what is known and asked. The male student is less complete in explaining the strategy and solving the steps of the problem. The result of research [28] that the mathematical communication skills of FD with different genders do not have much difference. The FD students are able to explain the situation, unable to present problems, able to represent the mathematics as a whole, have not been able to solve problems, unable to obtain solutions, and unable to interpret solutions. The dependent field is a characteristic of individuals who tend to organize and process information globally so that its perception is easily affected by environmental change [38]. Students with the cognitive style of the field-dependent are less capable of expressing mathematical ideas into the form of graphs, underprivileged in identifying early mathematical ideas in writing with their own language. FD students are less able to express mathematical ideas, understand, interpret and evaluate mathematical ideas, less capable of using terms, mathematical notation and present ideas, describing relations with the model of the situation [38].

\section{CONCLUSION}

The mathematical communication skills based on cognitive style (field-dependent and fieldindependent) was significant differences. The field-independent students are able to understand the information and re-explain what is known and asked precisely and clearly. They use notation, symbols, and mathematical models to describe the problem appropriately. They are able to explain the strategy and the steps to resolve the problem clearly. They are able to explain how to evaluate/check the settlement clearly and accurately. The field-dependent students are able to understand the information, but the explanation of what is known and asked less clearly and less complete. They use notation, symbols, and mathematical models to describe the problem appropriately. They are able to explain the strategy and troubleshooting steps, but are less complete. They are able to explain how to evaluate/check the settlement fairly clearly and accurately. The mathematical communication skills based on gender (male and female) do not have significant differences. Both male and female students can understand the information; explain what is known, and well-asked. They can use notations, symbols, and mathematical models to describe the problem/answer appropriately. They are also able to explain how to evaluate/check the settlement clearly and accurately. Male students are able to explain the strategy and solving the steps of the problem with a fairly obvious, but less structured; while, female students are able to explain the strategy and steps to resolve the problem clearly and structured. 


\section{REFERENCES}

[1] N. Rohid, et al., "Students' mathematical communication skills (MCS) in solving mathematics problems: A case in Indonesian context," Anatolian. Journal of Education, vol. 4, no. 2, pp. 19-30, 2019.

[2] NCTM, Principles, Standards for School Mathematics. United States of America: NCTM, 2000.

[3] J. Lee, "Oh, I just had it in my head": Promoting mathematical communications in early childhood," Contemporary Issues in Early Childhood, vol. 16, no. 3, pp. 284-287, 2015.

[4] A. Astuti and Leonard, "The role of mathematical communicaton skill towards student's mathematic achievement (in Bahasa)," Jurnal Formatif, vol. 2, no. 2, pp. 102-110, 2015.

[5] R. Ariawan and H. Nufus, "The relation of mathemathical problem solving skill with students' mathematic communication skill (in Bahasa)," THEOREMS (The Original Research of Mathematic), vol. 1, no. 2, pp. 82-91, 2017.

[6] H. Ulya, "The relation of cognitive style with students' mathematical problem-solving skill (in Bahasa)," Jurnal Konseling GUSJIGANG, vol. 1, no. 2, pp. 1-12, 2015.

[7] R. Junita, "Mathematical representation and communication abilities of high school students reviewed of learning achievement and cognitive style (in Bahasa)," Jurnal Pythagoras: Jurnal Pendidikan Matematika, vol. 11, no. 2, pp. 193-206, 2016.

[8] H. A. Witkin, The role of cognitive style in academic performance and in teacher-student relations. Research Bulletin. New Jersey: Educational Testing Service, 1973.

[9] M. Ibrahim, "Relationship between cognitif styles levels of cognitive thinking and chemistry achievement among form four science students," Unpublished note. Research report, Universiti Teknologi Malaysia, Kuala Lumpur, 2004.

[10] M. Kozhevnikov, "Cognitive styles in the context of modern psychology: Toward an integrated framework of cognitive style," Psychological Bulletin, vol. 133, no. 3, pp. 464-481, 2007.

[11] H. A. Witkin, "Field-dependent and field-independent cognitive styles and their educational implications," Review of Education Research, vol. 47, no. 1, pp. 1-64, 1977.

[12] U. Hamzah, New orientation on psychology learning (in Bahasa). Jakarta: PT. Bumi Aksara, 2010.

[13] Desmita, Psychology learning of students (in Bahasa). Bandung: PT. Remaja Rosdakarya, 2014.

[14] N. Istiqomah and E. B. Rahaju, "Junior high school students' thinking process on resolving mathematic story question based on cognitive style on the material of building curved sides," Journal Ilmiah Pendidikan Matematika, vol. 3, no. 2, pp. 144-149, 2014.

[15] M. Gufron and R. Risnawita, Learning style of theoretical studies (in Bahasa). Yogyakarta: Pustaka Pelajar, 2014.

[16] M. Yousefi, "Cognitive Style and EFL Learners' Listening Comprehension Ability," Indonesian Journal of Applied Linguistics, vol. 1, no. 1, pp. 73-83, 2011.

[17] I. Dewi, "The profile of the mathematical communication accuracy of student teacher candidates reviewed from gender differences (in Bahasa)," Journal Didaktik Mathematic, vol. 1, no. 2, pp. 1-12, 2014.

[18] M. Nafi'an, "Students ability on resolving story question reviewed from gender based in elementary school (in Bahasa)," Prosiding Seminar Nasional Matematika dan Pendidikan Matematika, Universitas Negeri Yogyakarta, 2011.

[19] E. E. Maccoby and C. N. Jacklin, The psychology of sex differences. Stanford: Stanford University, 1974.

[20] M. J. Legato, Why men never remember and women never forget. New York: Rodale, 2005.

[21] S. Yuliani, "Difference gender on mastery of language reviewed from psychology learning perspective (in Bahasa)," Pedagogi: Journal Ilmiah Ilmu Pendidikan, vol. 13, no. 1, pp. 47-51, 2013.

[22] J. W. Creswell, Reseach design: Qualitative approach, quantitative approach and mixed approach third edition (translated by Ahmatd Fawaid) (in Bahasa). Yogyakarta: Pustaka Pelajar, 2014.

[23] D. Mardapi, Technique of forming test instrument and non test instrument (in Bahasa). Yogyakarta: Mitra Cendika Press, 2008.

[24] Depdiknas, Technical guidance for making afektive assessment instrument at Senior High School (in Bahasa). Jakarta: Depdiknas, 2010.

[25] Z. Sulthani, "Reach students and regural student's mathematical communication skill of X SMA Panjura Malang on mathematical logic material (in Bahasa)," Jurnal Online Universitas Negeri Malang, vol. 1, no. 1, pp. 1-11, 2012.

[26] G. Corder and D. Foreman, Nonparametric statistics a step-by-step approach. Canada: John Wiley \& Sons, 2014.

[27] D. D. Pratiwi, "Analysis of mathematical communication ability on mathematical problem solving based on cognitive style and gender (in Bahasa)," Al Jabar, vol. 6, no. 2, pp. 131-142, 2015.

[28] D. Alenezi, "A study of learning mathematics related to some cognitive factors and to attitudes," Doctoral dissertation, University of Glasgow, 2008.

[29] R. Husna, "Improved mathematical problem-solving and communication skills through a realistic mathematics approach in grade VII Langsa junior high school students (in Bahasa)," Journal Pendidikan Matematika PARADIKMA, vol. 6, no. 2, pp. 175-186, 2013.

[30] M. Goos, et al., Teaching Secondary School Mathematics: Research and Practice for the 21st Century, 2nd Ed. Crown Nest, Sydney: Allen \& Unwin, 2017.

[31] W. Murtafiah, "Mathematical communication skill of mathematic teachers to be in resolving differential equations viewed from gender (in Bahasa)," Journal Math Educator Nusantara: Wahana Publikasi Karya Tulis Ilmiah Di Bidang Pendidikan Matematika, vol. 2, no. 1, pp. 31-41, 2016.

[32] Z. Amir, "Gender prespective on methematic learning (in Bahasa)," Jurnal Marwah, vol. 12, no. 1, pp. 15-31, 2013. 
[33] S. Prayitno, et al., "Junior high school students' mathematicl communication skill on resolving mathematic task viewed fom gender (in Bahasa)," Proceedings of the National Seminar on mathematics and mathematics education FMIPA UNY, Yogyakarta, 2013.

[34] S. Subarinah, "Profile of students' creative thinking in solving mathematical investigation type problems viewed from gender differences (in Bahasa)," Proceedings of the National Seminar on mathematics and mathematics education FMIPA UNY, Yogyakarta, 2013.

[35] R. D. Pinanti, "Student mathematical communication skill in resolving mathematic problem solving viewed from gender difference (in Bahasa)," MATHEdunesa, vol. 3, no. 3, pp. 215-220, 2015.

[36] H. Putra, et al., "Mathematical communication skills of students according to gender in solving problems on block and cube material (Case study on VIII grade junior high school students at Al-Azhar 29 Semarang Islamic Middle School) (in Bahasa)," Jurnal Elektronik Pembelajaran Matematika, vol. 4, no. 9, pp. 778-788, 2016.

[37] Y. S. Achir, B. Usodo, and R. Retiawan, "Analysis of students' mathematical communication ability in mathematical problem solving on two-variable linear equation system (SPLDV) material viewed from cognitive style (in Bahasa)," Paedagogia, vol. 20, no. 1, pp. 78-87, 2017.

[38] E. Pujianto and Masrukan, "Analysis of mathematical communication skills in a round club model with selfassessment and ethno-mathematical nuances based on cognitive styles (in Bahasa)," Unnes Journal of Mathematics Education Research, vol. 5, no. 1, pp. 81-89, 2016.

[39] Y. Putriana, "Analysis of mathematical communication skill based on junior high school student cognitive style (in Bahasa)," Bachelor's thesis, Universitas Muhammadiyah Purworejo, 2017.

Int. J. Eval. \& Res. Educ. Vol. 9, No. 4, December 2020: 847 - 856 